\title{
TAEKWONDO SCIENTIFIC PRODUCTION PUBLISHED ON THE WEB OF SCIENCE (1988-2016): COLLABORATION AND TOPICS
}

\author{
PRODUÇÃO CIENTIIFICA DE TAEKWONDO PUBLICADA NA WEB OF SCIENCE \\ (1988-2016): COLABORAÇÃO E TEMAS
}

\author{
PRODUCCIÓN CIENTÍFICA DE TAEKWONDO PUBLICADA EN LA WEB OF \\ SCIENCE (1988-2016): COLABORACIÓN Y TEMAS
}

\author{
Mikel Pérez-Gutiérrez*, Pablo Valdés-Badilla*, Carlos Gutiérrez-García ${ }^{* * *}$, \\ Tomás Herrera-Valenzuela ${ }^{* *+*}$
}

\section{Keywords:}

Bibliometrics.

Journal Article.

Professors.

Scientific

Communication and

Diffusion.

\begin{abstract}
This study conducted a bibliometric analysis focused on collaboration patterns and topics represented on taekwondo articles published on Web of Science until 2016. Bibliographic information was retrieved from documents and then classified according to research area, subject and topic, and characteristics of authorship and collaboration patterns were calculated. Results showed a total of 340 articles, 304 of which had multiple authors. Life Sciences and Biomechanics were the most important research area and subject respectively. Pieter was the most prolific author while Capranica obtained the highest collaboration index. In conclusion, (1) the relevance of a sporting approach to taekwondo has been corroborated through the analysis of research areas, subjects, topics, and journals' orientation and citation scores; (2) research on taekwondo has been strongly based on collaboration among authors, institutions and countries.
\end{abstract}

Palavras chave: Bibliometria.

Artigo de revista. Docentes.

Comunicação e divulgação científica. Bibliometría. Artículo de Revista.

Docentes.

Comunicación y Divulgación Científica.
Resumo: 0 objetivo foi desenvolver uma análise bibliométrica sobre padrões de colaboração e temas representados em artigos sobre taekwondo publicados na Web of Science até 2016. A informação bibliográfica de documentos foi recuperada. Em seguida, foram classificados em relação à área de pesquisa, assunto e tópico e calculadas as características de autoria e padrões de colaboração. Um total de 340 artigos foram encontrados, 304 de autoria múltipla. Ciências da Vida e Biomecânica foram a área de pesquisa e a disciplina mais importantes respectivamente. Pieter foi o autor mais prolífico enquanto Capranica obteve o maior índice de colaboração. Em conclusão, (1) a relevância da abordagem esportiva de taekwondo foi corroborada através da análise de áreas de pesquisa, disciplinas, temas, orientação e pontuações de citação das revistas; e (2) a pesquisa de taekwondo baseou-se fortemente na colaboração entre autores, instituições e países.

Resumen: El objetivo fue desarrollar un análisis bibliométrico centrado en los patrones de colaboración y temas representados en los artículos de taekwondo publicados en la Web of Science hasta 2016. Se recuperó la información bibliográfica de los documentos. Luego se clasificaron en relación al área de investigación, disciplina y tema, y calcularon las características de la autoría y patrones de colaboración. Los resultados mostraron 340 artículos en total, 304 en coautoría. Ciencias de la Vida y Biomecánica fueron el área de investigación y la disciplina más representadas respectivamente. Pieter fue el autor más prolífico mientras que Capranica obtuvo el índice de colaboración más alto. En conclusión, (1) la relevancia del enfoque deportivo del taekwondo fue corroborado a través del análisis de las áreas de investigación, disciplinas, temas, orientación y cifras de citación de las revistas; y (2) la investigación estuvo basada fundamentalmente en la colaboración entre autores, instituciones y países.
*Universidad de Cantabria. Santander, Espanha.

E-mail: mikel.perez@unican.es

**Universidad Autónoma de Chile. Temuco, Chile.

E-mail: pablo.valdes@uautonoma.cl

***Universidad de León. León, Espanha.

E-mail: cgutg@ unileon.es

${ }^{* * * * U n i v e r s i d a d ~ d e ~ S a n t i a g o ~ d e ~ C h i l e . ~}$ Santiago, Chile.

E-mail: tomas.herrera@usach.cl

Recebido em: 05-09-2017 Aprovado em: 21-10-2017

$\mathrm{DOl}$ http://dx.doi.org/10.22456/1982-8918.75386 (c) (1) (8) Licence 


\section{INTRODUCTION}

Taekwondo has been considered one of the most important martial arts and combat sports (MA\&CS) in the world because of its debut as an official Olympic sport in 2000 Sydney Olympic Games and its amount of practitioners (SVINTH, 2010). Its relevance is also depicted on the rise of scientific articles on this topic published from the last decades of the $20^{\text {th }}$ century onwards and the several institutions managing the development of taekwondo (PÉREZ-GUTIÉRREZ et al., 2015; WIZDOM.Al, 2017). These international organizations have also contributed to the dissemination of knowledge about taekwondo, publishing their own journals such as Taekwondo Journal of Kukkiwon (KUKKIWON, 2017), Taekwon-Do Research Journal (ITF, 2017), Journal of the International Association for Taekwondo Research (IATR, 2017), Taekwondo (WTF, 2017) and Tae Kwon Do Journal (ITA, 2017).

The increasing popularity and interest on taekwondo together with the rise of information about it have also triggered the appearance of several websites dedicated to the spreading of results, events, news, rankings or studies about this MA\&CS in order to report its evolution and current news (ITRC, 2017; MASTAEKWONDO, 2017; TAEKWONDO RADIO, 2017; TAEKWONDODATA, 2017; TAEKWONDOSCIENCE, 2017; TKD TIMES, 2017). In addition, global scientific production has become enormous and new techniques of analysis have appeared for evaluating scientific development. In this way, bibliometrics has turned the main tool for this purpose (THOMSON REUTERS, 2008), being applied to aspects of science such as productivity, topics, collaboration and citation (ANDRÉS, 2009; LÓPEZ LÓPEZ, 1996).

To date, several works have studied martial arts from a bibliometric approach, focusing on scientific production in martial arts in Spain (GUTIÉRREZ-GARCÍA; PÉREZ-GUTIÉRREZ, 2009); Asian martial arts monographs (PÉREZ-GUTIÉRREZ, 2012; PÉREZ-GUTIÉRREZ; GUTIÉRREZGARCÍA, 2008) or journals (GUTIÉRREZ-GARCÍA; BRIEVA-ORTEGA; PÉREZ-GUTIÉRREZ, 2011); karate monographs published in Spain (PÉREZ-GUTIÉRREZ; GUTIÉRREZ-GARCÍA, 2009) and Czech Republic (ČIHOUNKOVÁ; REGULI, 2011; VIT; REGULI, 2011); or scientific literature about judo (PESET et al., 2013).

Furthermore, bibliometrics has been also applied to taekwondo for studying its articles published in Scopus and Web of Knowledge (LEE, 2015), Science Direct, Scopus and Web of Knowledge (COTA-GUAJARDO, 2013), Web of Science (PÉREZ-GUTIÉRREZ et al., 2015) as well as its Latin-American scientific production (PÉREZ-GUTIÉRREZ; VALDÉS-BADILLA, 2014). In particular, the study carried out by PÉREZ-GUTIÉRREZ et al. (2015) was focused on the analysis of productivity and topics depicted on taekwondo research published in the Web of Science (WoS) until 2013. Their work presented an overview of taekwondo research characteristics, depending on the information and document classification offered by the WoS. However, documents are not individually classified according to their research area, since these areas are assigned at the journal level (THOMSON REUTERS, 2009). In order to solve this problem and for deepening in the features surrounding taekwondo research published in WoS, the present study was developed.

To the best of our knowledge, no works have been carried out for studying the collaboration patterns within taekwondo, although this kind of analysis offers an overview of the social structure of the scientific community within a certain field of knowledge (LÓPEZ LÓPEZ, 1996). Therefore, the aim of the present work was to develop a bibliometric analysis focused on collaboration as well as the analysis of topics represented on taekwondo articles published in the Web of Science until 2016. 


\section{METHODOLOGY}

Taekwondo article or review documents published from 1900 to 2016 (inclusive) in the Web of Science (WoS) databases such as Science Citation Index Expanded (SCI-EXPANDED), Social Sciences Citation Index (SSCl) and Arts \& Humanities Citation Index (A\&HCl) were included in the present study. Article or review documents focused on taekwondo or including taekwondo practitioners among their sample were selected.

\subsection{Data mining}

In relation to search strategies and attending to PÉREZ-GUTIÉRREZ; GUTIÉRREZGARCÍA; ESCOBAR-MOLINA (2011) recommendations, taekwondo, taekwando, tae-kwondo, tae-kwan-do and taekwon-do terms were used for data mining and they were individually introduced in the topic field. The search was done from 1900 to 2016 (inclusive) for obtaining a comprehensive data retrieval and filtered by document type for including article and review documents only. Data mining was performed on May, 2017.

After filtering results, articles' and reviews' bibliographic information was exported and registered in Endnote X6 reference manager programme following the recommendations of the Spanish Association for Standardization and Certification (AENOR, 2013), saving the full record and cited references of each document. Before performing data analysis, duplicate records were checked and author's and institution's name were standardized for avoiding different spellings.

\subsection{Data analysis}

Data analysis was focused on the bibliometric analysis of topics and collaboration patterns. Firstly, documents were classified according to their subject and research area, following the criteria used by DEVÍS-DEVÍS et al. (2010) and the research areas proposed by the WoS (THOMSON REUTERS, 2012) respectively. Moreover, documents were classified ad hoc attending to their main topic for presenting articles' goals and complementing subject classification, since the same topic could be studied from different subjects or approaches.

Secondly and related to collaboration patterns, single-authored articles (SA), multiauthored articles (MA), total articles (TA), mean of authors per article and percentage of collaboration $(\% \mathrm{C})$ were calculated and distributed per year. Percentage of collaboration $(\% \mathrm{C})$ was calculated using the formula given by Valenciano Valcárcel et al. (2010), being: \%C = MA/ TA. Moreover, number of articles, signatures, collaborators and collaboration index were also calculated for those authors with seven or more articles.

Then, two softwares were used for analysing the most productive journals and creating the co-authorship network. Following the same methodology used by Peset et al. (2013), Bibexcel and Histcite were selected for calculating the number of published documents, number of citations in the collection to the journal (Total Local Citation Score; TLCS), total citations in WoS to papers in the journal in the collection (Total Global Citation Score; TGCS) as well as the co-authorship structure. Therefore, TLCS is the number of times a journal included in the present results has been cited by other papers within the present results while TGCS is the number of times that papers in a journal included in the present results has been cited in the WoS database. Finally, Pajek software was used for drawing scientific networks map, representing clusters with more than three members for the scientific network. 


\section{RESULTS}

A total of 340 articles, published between 1988 and 2016, were selected. The bibliometric analysis carried showed four research areas and 14 subjects with a heterogeneous development in taekwondo's scientific production (Table 1). Life Sciences was the most represented area involved in taekwondo's research, obtaining 257 articles (75.6\%), followed by Social Sciences with 65 (19.1\%). On the other hand, Technology and Arts \& Humanities areas compiled only 18 publications $(5.3 \%)$. In relation to subjects, the most prominent were Biomechanics with 77 articles (22.6\%), Sports Medicine with 60 (17.6\%) and Physiology with 56 (16.5\%); all of them pertaining to Life Sciences. Within Social Sciences, Psychology was the most represented subject with 45 articles (13.2\%). On the other hand, Kinesiology and Psychomotor Education were only presented in 5 articles while 1 article was classified within Robotics subject (Table 1).

Table 1 - Frequency distribution of published articles by year of publication, research area and subject.

\begin{tabular}{|c|c|c|c|c|c|c|c|c|c|c|c|c|c|c|c|c|c|c|c|c|c|c|c|c|c|c|c|c|c|c|c|}
\hline $\begin{array}{c}\text { Research area } \\
\text { \& subject }\end{array}$ & $\vec{Ð}$ & & & & & & $\ddot{\rightleftarrows}$ & & $\vec{\sharp}$ & & $\overrightarrow{0}$ & $\vec{\varnothing}$ & $\vec{ष}$ & & స్ & О్. & & 额 & 灾 & ธั. & 。్ర & : & Оั. & 옹 & $\stackrel{\text { O}}{\underline{\Xi}}$ & $\frac{O}{N}$ & $\frac{\tilde{O}}{\omega}$ & & 农 & & 올 \\
\hline $\begin{array}{l}\text { Arts \& } \\
\text { Humanities }\end{array}$ & 0 & 0 & 0 & 0 & 0 & 0 & 0 & 0 & 0 & 0 & 0 & 0 & 0 & 0 & 0 & 0 & 0 & 0 & 0 & 0 & 0 & 0 & 1 & 0 & 0 & 2 & 1 & 1 & 0 & 2 & 7 \\
\hline History & & & & & & & & & & & & & & & & & & & & & & & 1 & & & 2 & 1 & 1 & & 2 & 7 \\
\hline Life Sciences & 1 & 1 & 1 & 2 & 1 & 1 & 0 & 0 & 1 & 1 & 2 & 3 & 3 & 0 & 3 & 5 & 3 & 4 & 6 & 6 & 11 & 9 & 13 & 12 & 31 & 30 & 26 & 26 & 29 & & 257 \\
\hline Biomechanics & & 1 & & 1 & & & & & & 1 & & & & & & 1 & & 1 & & 2 & 2 & 2 & 4 & 3 & 10 & 10 & 12 & 5 & 8 & 14 & 77 \\
\hline Sports Medicine & 1 & & & 1 & 11 & 1 & & & 1 & & 2 & 1 & 3 & & 2 & 2 & 1 & 2 & 3 & 1 & 3 & 2 & 5 & 2 & 5 & 6 & 3 & 3 & 5 & 5 & 60 \\
\hline Physiology & & & 1 & & & & & & & & & 2 & & & 1 & 1 & & 1 & 3 & 2 & 2 & 1 & 3 & 3 & 10 & 9 & 1 & 8 & 6 & 2 & 56 \\
\hline Nutrition & & & & & & & & & & & & & & & & & & & & 1 & 3 & 2 & & 2 & 3 & 3 & 4 & 5 & 2 & 3 & 28 \\
\hline $\begin{array}{l}\text { Sports Training } \\
\text { Theory }\end{array}$ & & & & & & & & & & & & & & & & 1 & & & & & 1 & 2 & & & 1 & 2 & 4 & 3 & 5 & 3 & 22 \\
\hline Anthropometry & & & & & & & & & & & & & & & & & 1 & & & & & & & & 1 & & 2 & 2 & 3 & & 9 \\
\hline Kinesiology & & & & & & & & & & & & & & & & & 1 & & & & & & 1 & 2 & 1 & & & & & & 5 \\
\hline $\begin{array}{l}\text { Social } \\
\text { Sciences }\end{array}$ & 0 & 0 & 1 & 1 & 1 & 1 & 1 & 1 & 1 & 1 & 2 & 1 & 0 & 1 & 1 & 1 & 0 & 4 & 0 & 3 & 2 & 0 & 5 & 3 & 3 & 3 & 6 & 8 & 9 & 6 & 65 \\
\hline Psychology & & & 1 & 1 & 1 & 1 & 1 & 1 & 1 & 1 & 2 & 1 & & & 1 & 1 & & 3 & & 2 & 1 & & 3 & 1 & 3 & 3 & 4 & 4 & 6 & 3 & 45 \\
\hline Sociology & & & & & & & & & & & & & & 1 & & & & & & & & & 2 & & & & 1 & 1 & 2 & 2 & 9 \\
\hline PE \& ST & & & & & & & & & & & & & & & & & & & & 1 & 1 & & & & & & & 2 & 1 & 1 & 6 \\
\hline $\begin{array}{l}\text { Psychomotor } \\
\text { Education }\end{array}$ & & & & & & & & & & & & & & & & & & 1 & & & & & & 2 & & & 1 & 1 & & & 5 \\
\hline Technology & 0 & 0 & 0 & 0 & 0 & 0 & 0 & 0 & 0 & 0 & 0 & 0 & 0 & 0 & 0 & 0 & 1 & 0 & 0 & 1 & 0 & 1 & 1 & 3 & 1 & 1 & 1 & 0 & 0 & 1 & 11 \\
\hline Documentation & & & & & & & & & & & & & & & & & 1 & & & 1 & & 1 & 1 & 3 & 1 & 1 & 1 & & & & 10 \\
\hline Robotics & & & & & & & & & & & & & & & & & & & & & & & & & & & & & & 1 & 1 \\
\hline Total & 1 & 1 & 2 & 3 & 32 & 2 & 1 & 1 & 2 & 2 & 4 & 4 & 3 & 1 & 4 & 6 & 4 & 8 & 6 & 10 & 13 & 10 & 20 & 18 & 35 & 36 & 34 & 35 & 38 & & 340 \\
\hline
\end{tabular}

Regarding the distribution of articles per topic, 101 different topics were found, being injuries the most represented one with 61 articles (17.94\%) while 76 topics appeared in three or less publications respectively and compiled 115 publications in total (33.82\%) (Table 2). 
Table 2 - Frequency, percentage and cumulative percentage of published articles by topic.

\begin{tabular}{|c|c|c|c|}
\hline Topic & $n$ & $\%$ & Cumulative $\%$ \\
\hline Injuries & 61 & 17.94 & 17.94 \\
\hline Biomechanical analysis & 15 & 4.41 & 22.35 \\
\hline Physiological response & 13 & 3.82 & 26.18 \\
\hline Protective gear & 11 & 3.24 & 29.41 \\
\hline Anthropometric profile & 8 & 2.35 & 31.76 \\
\hline Kick performance & 8 & 2.35 & 34.12 \\
\hline Strength & 8 & 2.35 & 36.47 \\
\hline Testing techniques & 8 & 2.35 & 38.82 \\
\hline Weight loss & 8 & 2.35 & 41.18 \\
\hline Balance & 7 & 2.06 & 43.24 \\
\hline Technical-Tactical Analysis & 7 & 2.06 & 45.29 \\
\hline Anxiety & 6 & 1.76 & 47.06 \\
\hline Fitness & 6 & 1.76 & 48.82 \\
\hline Food supplementation & 6 & 1.76 & 50.59 \\
\hline Heart rate & 6 & 1.76 & 52.35 \\
\hline Magnesium & 6 & 1.76 & 54.12 \\
\hline Performance & 6 & 1.76 & 55.88 \\
\hline Bone density & 5 & 1.47 & 57.35 \\
\hline Impact force & 5 & 1.47 & 58.82 \\
\hline Personality & 5 & 1.47 & 60.29 \\
\hline History & 4 & 1.18 & 61.47 \\
\hline Hydration & 4 & 1.18 & 62.65 \\
\hline Success Factors & 4 & 1.18 & 63.82 \\
\hline Time-motion analysis & 4 & 1.18 & 65.00 \\
\hline Training load & 4 & 1.18 & 66.18 \\
\hline Anaerobic Capacity & 3 & 0.88 & 67.06 \\
\hline Anger & 3 & 0.88 & 67.94 \\
\hline Cardiovascular Diseases & 3 & 0.88 & 68.82 \\
\hline Hormones & 3 & 0.88 & 69.71 \\
\hline Immune system & 3 & 0.88 & 70.59 \\
\hline Motivation & 3 & 0.88 & 71.47 \\
\hline Postural control & 3 & 0.88 & 72.35 \\
\hline Torque & 3 & 0.88 & 73.24 \\
\hline Age effect & 2 & 0.59 & 73.82 \\
\hline Aggressiveness & 2 & 0.59 & 74.41 \\
\hline Blood Lactate & 2 & 0.59 & 75.00 \\
\hline Body Image & 2 & 0.59 & 75.59 \\
\hline Caffeine & 2 & 0.59 & 76.18 \\
\hline Cognition & 2 & 0.59 & 76.76 \\
\hline Coordination & 2 & 0.59 & 77.35 \\
\hline Cultural identity & 2 & 0.59 & 77.94 \\
\hline Doping & 2 & 0.59 & 78.53 \\
\hline Energy Demands & 2 & 0.59 & 79.12 \\
\hline Food Habits & 2 & 0.59 & 79.71 \\
\hline Others & 69 & 20.29 & 100 \\
\hline
\end{tabular}


Regarding the collaboration patterns, taekwondo scientific production published in the WoS was mainly developed in groups with a total of 304 multi-authored articles. In this way, until the beginning of the $21^{\text {st }}$ century the evolution of the percentage of collaboration shows that there existed a clear predominance towards collaborative works. From 2000 onwards, there has been a slight rise in the number of single-authored articles, decreasing the percentage of collaboration (Table 3).

Table 3 - Distribution of the amount of single-authored articles, multi-authored articles, total articles and percentage of collaboration per year.

\begin{tabular}{|c|c|c|c|c|}
\hline Year & Single authored papers & Multi-authored papers & Total papers & $\%$ of collaboration \\
\hline 1988 & 0 & 1 & 1 & 100 \\
\hline 1989 & 0 & 1 & 1 & 100 \\
\hline 1990 & 1 & 1 & 2 & 50 \\
\hline 1991 & 0 & 3 & 3 & 100 \\
\hline 1992 & 0 & 2 & 2 & 100 \\
\hline 1993 & 0 & 1 & 1 & 100 \\
\hline 1994 & 0 & 1 & 1 & 100 \\
\hline 1995 & 0 & 2 & 2 & 100 \\
\hline 1996 & 0 & 2 & 2 & 100 \\
\hline 1997 & 0 & 4 & 4 & 100 \\
\hline 1998 & 0 & 4 & 4 & 100 \\
\hline 1999 & 0 & 3 & 3 & 100 \\
\hline 2000 & 1 & 0 & 1 & 0 \\
\hline 2001 & 2 & 2 & 4 & 50 \\
\hline 2002 & 0 & 6 & 6 & 100 \\
\hline 2003 & 0 & 4 & 4 & 100 \\
\hline 2004 & 2 & 6 & 8 & 75 \\
\hline 2005 & 0 & 6 & 6 & 100 \\
\hline 2006 & 2 & 8 & 10 & 80 \\
\hline 2007 & 3 & 10 & 13 & 76.92 \\
\hline 2008 & 0 & 10 & 10 & 100 \\
\hline 2009 & 2 & 18 & 20 & 90 \\
\hline 2010 & 4 & 14 & 18 & 77.78 \\
\hline 2011 & 3 & 32 & 35 & 91.43 \\
\hline 2012 & 6 & 30 & 36 & 83.33 \\
\hline 2013 & 1 & 33 & 34 & 97.06 \\
\hline 2014 & 2 & 33 & 35 & 94.29 \\
\hline 2015 & 4 & 34 & 38 & 89.47 \\
\hline 2016 & 3 & 33 & 36 & 91.67 \\
\hline Total & 36 & 304 & 340 & 87.39 \\
\hline
\end{tabular}

Source: prepared by authors.

Regarding the mean of authors per article, it ranges from 1 to 4.42 showing a considerable variability along time. However, from 2005 onwards the mean of authors per article was over 3 (Figure 1). 
Figure 1 - Mean of authors per article distributed by year.

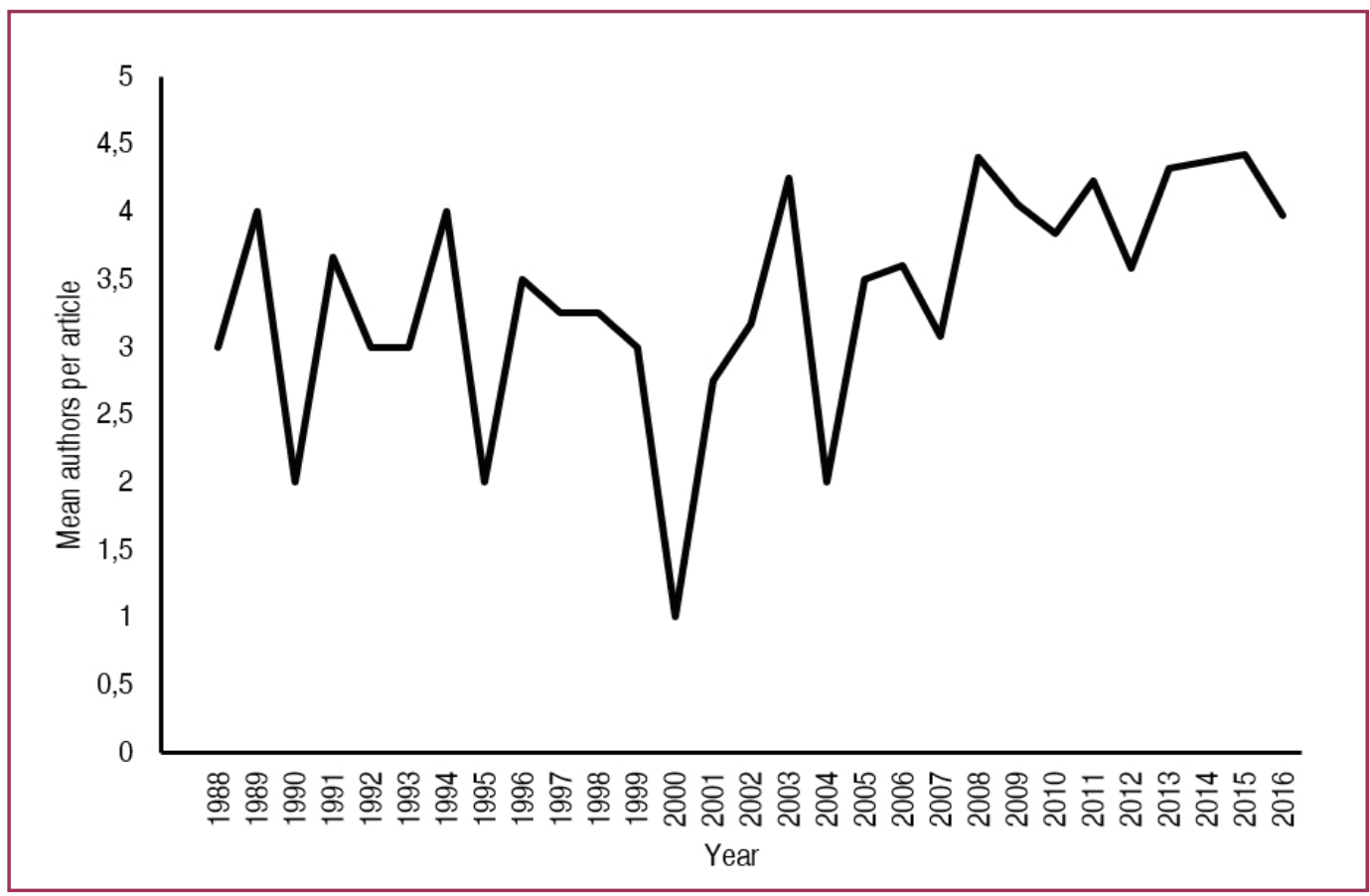

Source: prepared by authors.

Table 4 illustrates the collaboration patterns of the most productive authors, highlighting Pieter as the most prolific with 19 publications, followed by Wasik with 14 articles. The collaboration index of the most productive authors ranged from 1.36 to 7.22 , but a direct relationship between the amount of published articles and the collaboration index is not appreciated, since Pieter published the largest number of articles and his collaboration index was 3.26. In the same way, the collaboration indexes of Fife and Fong were 3.43 and 3.29 respectively, lower than those obtained by other authors with the same amount of publications, such as Tessitore (6.43) and Chaouachi (6.29).

On the other hand, the number of collaborators of the most productive authors fluctuated from 5 to 56, representing the extent of their collaboration network. With the exception of Wasik, those authors with five or more articles have a collaboration network composed by at least 9 different researchers.

Table 4 - List of most productive authors ( $\geq 5$ papers), with institutional affiliations and collaboration patterns.

\begin{tabular}{lccccc}
\hline Author & Papers & Signatures & $\begin{array}{c}\text { Collaboration } \\
\text { Index }\end{array}$ & Collaborators & Current institutional affiliation \\
\hline W. Pieter & 19 & 62 & 3.26 & 43 & Masaryk University, Czech Republic \\
\hline J. Wasik & 14 & 19 & 1.36 & 5 & Jan Dlugosz University, Poland \\
\hline C. Falco & 13 & 53 & 4.08 & 40 & University of Bergen, Norway \\
\hline I. Estevan & 12 & 50 & 4.17 & 38 & University of Valencia, Spain \\
\hline E. Franchini & 10 & 42 & 4.20 & 32 & University of Sao Paulo, Brazil \\
\hline L. Capranica & 9 & 65 & 7.22 & 56 & University of Rome Foro Italico, Italy \\
\hline S. Chiodo & 9 & 54 & 6.00 & 45 & Magna Graecia University of Catanzaro, Italy \\
\hline D.M. O'Sullivan & 9 & 36 & 4.00 & 27 & Pusan National University, South Korea \\
\hline A.K. Baltaci & 8 & 35 & 4.38 & 27 & Selcuk University, Turkey \\
\hline R. Mogulkoc & 8 & 35 & 4.38 & 27 & Selcuk University, Turkey \\
\hline & & & & & Continues on the next page...
\end{tabular}


Table 4 ...

\begin{tabular}{lccccc}
\hline A. Chaouachi & 7 & 44 & 6.29 & 37 & $\begin{array}{c}\text { National Centre of Medicine \& Science in } \\
\text { Sports, Tunisia }\end{array}$ \\
\hline A. Tessitore & 7 & 45 & 6.43 & 38 & University of Rome Foro Italico, Italy \\
\hline G.P. Fife & 7 & 24 & 3.43 & 17 & $\begin{array}{c}\text { Texas State University, United States of } \\
\text { America }\end{array}$ \\
\hline S.S.M. Fong & 7 & 23 & 3.29 & 16 & $\begin{array}{c}\text { Hong Kong Institute of Education, Peoples } \\
\text { Republic of China }\end{array}$ \\
\hline C. Cortis & 6 & 40 & 6.67 & 34 & University of Rome Foro Italico, Italy \\
\hline C. Lupo & 6 & 40 & 6.67 & 34 & University of Rome Foro Italico, Italy \\
\hline O. Alvarez & 6 & 28 & 4.67 & 22 & University of Valencia, Spain \\
\hline V. Cinar & 6 & 22 & 3.67 & 16 & Selcuk University, Turkey \\
\hline C.A. Bridge & 5 & 19 & 3.80 & 14 & Edge Hill University, United Kingdom \\
\hline C.K. Chang & 5 & 25 & 5 & 20 & National Taiwan University of Sport, Taiwan \\
\hline G.Y.F. Ng & 5 & 14 & 2.80 & 9 & Hong Kong Polytechnic University, Peoples \\
Republic of China
\end{tabular}

The map of the collaboration patterns shows the existence of seven networks with at least four academics (Figure 2). Usually, there exist a relationship among all the academics being part of the same network, but there is a case in which the network is led by an author (i.e. Pieter). Regarding the institutional collaboration networks depicted on Figure 2, five institutions are collaborating in each network at the most, with the exception of the network led by Pieter in which appears almost as many institutions (12) as authors (14) making up this network.

Figure 2- Author clusters (>3 members) when a threshold of $\geq 3$ co-authored publications is applied.

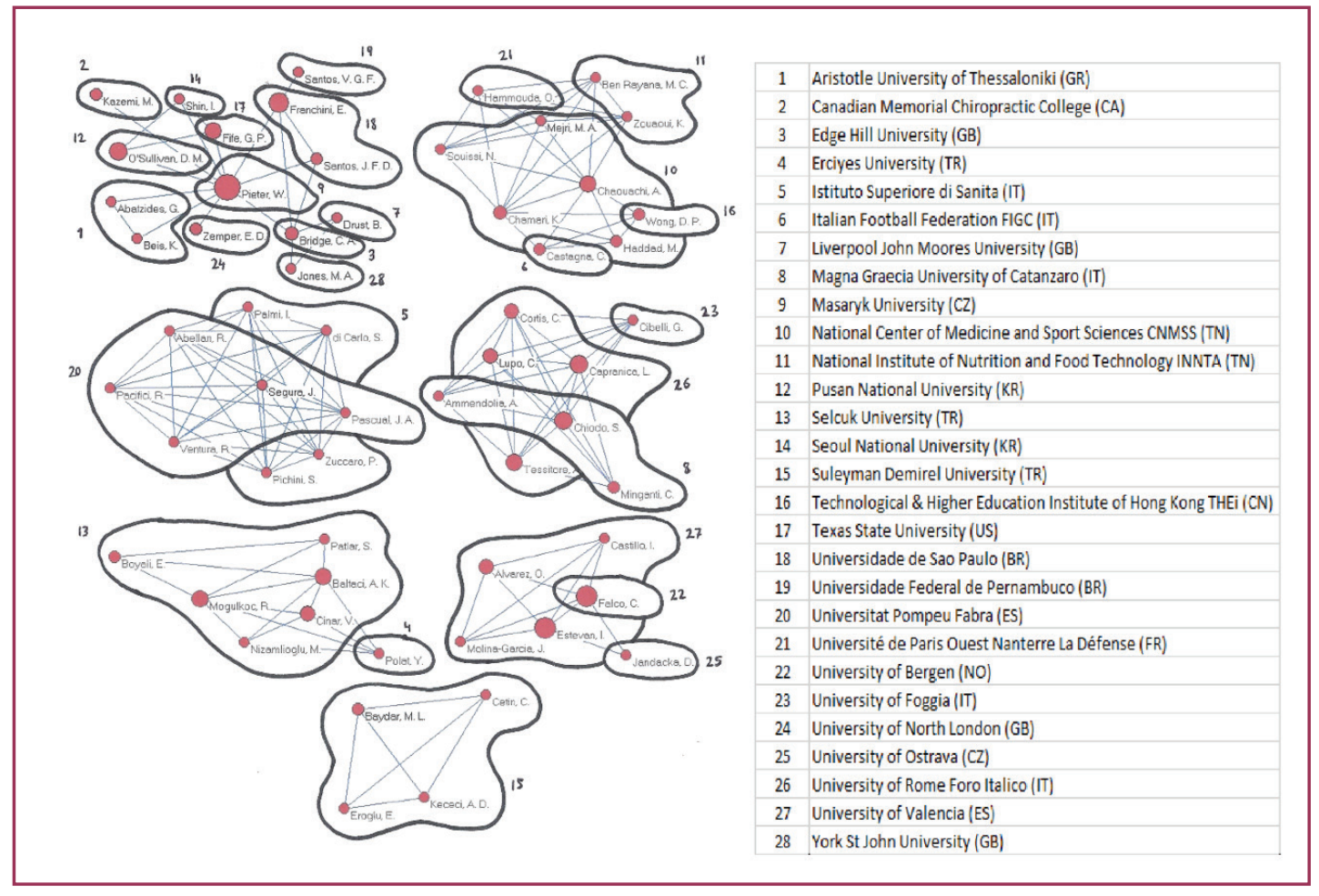


Finally, nine journals have published at least eight articles on taekwondo, compiling the $35.88 \%$ of total articles, while the 29 journals shown in Table 5 collected the $60.59 \%$ of total scientific output. The Journal of Strength and Conditioning Research (JSCR) together with the Journal of Sports Sciences (JSS) and the British Journal of Sports Medicine (BJSM) are the journals with the highest amount of citations in the collection (TLCS), receiving 143, 80 and 75 citations respectively. They also achieved the highest citation indexes in the WoS (TGCS) with 308 (BJSM), 261 (JSCR) and 184(JSS) citations (Table 5). In general, it seems there is a similar pattern or trend among TLCS and TGCS. On the other hand, Archives of Budo, a specific martial arts and combat sports oriented journal, is the most important journal for the dissemination of taekwondo's research, presenting a moderate TLCS and a high TGCS in relation to the rest of journals.

Table 5- Source journals for the articles and citations.

\begin{tabular}{|c|c|c|c|c|c|}
\hline Journal & Articles & $\%$ & Cumulative $\%$ & TLCS & TGCS \\
\hline Archives of Budo & 36 & 10.59 & 10.59 & 59 & 184 \\
\hline Journal of Strength and Conditioning Research & 14 & 4.12 & 14.71 & 143 & 261 \\
\hline Perceptual and Motor Skills & 13 & 3.82 & 18.53 & 37 & 140 \\
\hline British Journal of Sports Medicine & 12 & 3.53 & 22.06 & 75 & 308 \\
\hline Journal of Sports Science and Medicine & 12 & 3.53 & 25.59 & 53 & 132 \\
\hline Biology of Sport & 10 & 2.94 & 28.53 & 16 & 49 \\
\hline Journal of Human Kinetics & 9 & 2.65 & 31.18 & 13 & 24 \\
\hline Journal of Physical Therapy Science & 8 & 2.35 & 33.53 & 4 & 16 \\
\hline Journal of Sports Sciences & 8 & 2.35 & 35.88 & 80 & 184 \\
\hline Biological Trace Element Research & 6 & 1.76 & 37.65 & 3 & 52 \\
\hline Journal of Sports Medicine and Physical Fitness & 6 & 1.76 & 39.41 & 84 & 145 \\
\hline Collegium Antropologicum & 5 & 1.47 & 40.88 & 37 & 64 \\
\hline Dental Traumatology & 5 & 1.47 & 42.35 & 13 & 96 \\
\hline International Journal of the History of Sport & 5 & 1.47 & 43.82 & 4 & 8 \\
\hline Medicina dello Sport & 5 & 1.47 & 45.29 & 2 & 3 \\
\hline PLOS ONE & 5 & 1.47 & 46.76 & 0 & 17 \\
\hline Science \& Sports & 5 & 1.47 & 48.24 & 38 & 66 \\
\hline Acta of Bioengineering and Biomechanics & 4 & 1.18 & 49.41 & 7 & 14 \\
\hline Clinical Journal of Sport Medicine & 4 & 1.18 & 50.59 & 16 & 83 \\
\hline European Journal of Applied Physiology & 4 & 1.18 & 51.76 & 23 & 96 \\
\hline International Journal of Sport Psychology & 4 & 1.18 & 52.94 & 0 & 267 \\
\hline International Journal of Sports Medicine & 4 & 1.18 & 54.12 & 8 & 28 \\
\hline $\begin{array}{l}\text { International Journal of Sports Physiology and } \\
\text { Performance }\end{array}$ & 4 & 1.18 & 55.29 & 39 & 99 \\
\hline American Journal of Sports Medicine & 3 & 0.88 & 56.18 & 7 & 143 \\
\hline European Journal of Sport Science & 3 & 0.88 & 57.06 & 8 & 20 \\
\hline $\begin{array}{l}\text { International Journal of Sport Nutrition and Exercise } \\
\text { Metabolism }\end{array}$ & 3 & 0.88 & 57.94 & 4 & 61 \\
\hline Journal of Pharmaceutical and Biomedical Analysis & 3 & 0.88 & 58.82 & 2 & 25 \\
\hline Journal of Science and Medicine in Sport & 3 & 0.88 & 59.71 & 27 & 77 \\
\hline Journal of the International Society of Sports Nutrition & 3 & 0.88 & 60.59 & 0 & 6 \\
\hline Others & 134 & 39.41 & 100 & - & - \\
\hline
\end{tabular}

TLCS - Total Local Citation Score $=$ Total citations in the collection to the journal. TGCS - Total Global Citation Score $=$ Total citations in WoS to papers in the journal in the collection. (Note that this is not necessarily the total citations to the journal in WoS; only to those papers in the journal included in the collection). Source: prepared by authors. 


\section{DISCUSSION}

The scientific articles about taekwondo published in the WoS has shown the existence of four research areas focusing on this MA\&CS, being the Life Sciences the most represent one (75.6\%). In this way, Biomechanics, Sports Medicine and Physiology were the main subjects compiling 193 articles (56.8\%) (Table 1). The distribution of articles per topic showed academics' interest in biomechanical, physiological and nutritional aspects related to taekwondo (Table 2), among which the analysis of injuries was the most important one (17.94\%).

These results should be compared with those found by Pérez-Gutiérrez et al. (2015) due to the methodological approach they used for classifying the articles. These authors followed the classification carried out by the WoS, which was based on the research area of the journal where articles were published, while the present study developed an ad hoc classification of each article attending to their research area, subject and topic. This methodology caused the disappearance of Sport Sciences as the main subject (57.4\%) studying taekwondo (PÉREZGUTIÉRREZ et al., 2015), being replaced by Biomechanics, Sports Medicine and Physiology, which compiled a total of $56.8 \%$ of publications. Moreover, the trend of taekwondo research towards sports field (PÉREZ-GUTIÉRREZ et al., 2015) has been corroborated observing that the main analyzed topics (Table 2) are related to taekwondo's training and competition aspects.

In the same way, the study developed by Peset et al. (2013) used the classification of articles proposed by the WoS for pointing out a predominance of Sport Sciences followed by Physiology and Orthopedics for judo articles. Thus, the sporting side of taekwondo and judo seems to lead academics' attention and efforts to those aspects related to the performance on these MA\&CS. In the case of taekwondo, its inclusion in the programme of the Olympic Games in Sydney 2000 was mentioned as one of the possible reasons explaining the development of research in this area (PÉREZ-GUTIÉRREZ et al., 2015), but also it could justify researchers' attention to the sporting aspects of taekwondo. In the same way, Peset et al. (2013) stated the possible relationship among judo's sport results and research carried out in each country.

Regarding the collaboration patterns, the present study showed that the scientific production about taekwondo published in the WoS has been mainly developed collaboratively, achieving an $89.41 \%$ of multi-authored articles (Table 3) and a mean of 3.40 authors per article (Figure 1). However, the percentage of collaboration presented a decrease from 2000 onwards with the appearance of single-authored articles, although the mean of authors per article seems to indicate an increasing trend with values over 3 (Figure 1) and the amount of multi-authored articles also raised progressively (Table 3 ). Furthermore, the most productive authors also depicted a wide cooperation with other academics, ranging their collaboration index from 1.36 to 7.22 and their amount of collaborators from 5 to 56 (Table 4).

In the case of the articles about judo published in the WoS, Peset et al. (2013) obtained a group of 25 authors publishing five or more articles, with a mean of 2.40 authors per article, while the present study presented a total of 24 authors with a mean of 3.33 authors per article. On the one hand, the amount of the most productive authors in both MA\&CS is related to the number of published articles with similar results in both cases, since judo and taekwondo publications were 383 and 340 respectively. On the other hand, the mean of authors per article seems to point out a higher collaboration in taekwondo research. Peset et al. (2013) did not calculate the total mean of authors per article but showed six collaboration networks for those articles written 
by at least three authors, while the present study obtained a mean of 3.40 authors per article and seven networks, suggesting a more fluid collaboration in taekwondo research. However, the time span analyzed should be taken into account, since Peset et al. (2013) performed their search on June 2011 while the present work's time span ranged from 1900 to 2016, at least 5 years longer. As it has been depicted in both studies, from 2000 onwards there has existed a progressive increase in the amount of articles about judo and taekwondo so a similar pattern of publication should be expected from 2011 to 2016. In this way, differences between judo and taekwondo research could be higher than those shown here.

Regarding the collaboration networks, Figure 2 illustrates the collaborative bonds and networks of the publications written by at least three co-authors together with their institutional affiliations, helping to visualize the size and patterns of collaboration among academics and institutions. In taekwondo research, there exist seven clusters with more than 3 authors, collaborating 28 institutions from 13 different countries, being Italy and United Kingdom the most represented ones with 5 institutions respectively. Capranica followed by Cortis, Lupo and Tessitore were the most collaborative academics, all of them pertaining to the University of Rome Foro Italico (Italy). In the same way, Peset et al. (2013) depicted a similar situation in judo research, including the largest six networks the collaboration of 10 institutions from seven different countries and four authors were located in a central position in their own networks.

The collaboration structure of taekwondo showed that all researchers integrating a network tend to mix each other, being affiliated to a maximum of five different institutions. However, the most productive author (i.e. Pieter) achieved one of the lowest collaboration indexes (3.26) despite he cooperated with 43 academics, depicting his network a star distribution. As shown in Figure 2, Pieter has been the principal author and collaborated with 13 academics pertaining to different institutions. In this way, Pieter is the researcher leading and guiding taekwondo studies, not only due to the amount of published articles but for the number of authors, institutions and countries with which he has collaborated.

Finally, $60.59 \%$ of taekwondo documents have been published in 29 journals. The relevance of these journals is determined by their own citation indexes (TLCS and TGCS). The Journal of Strength and Conditioning Research together with the Journal of Sports Sciences and the British Journal of Sports Medicine, all of them oriented to Sport Sciences, are those journals with the highest citation indexes (Table 5) despite the differences in the amount of published articles. These data are similar to those found by PESET et al. (2013) where journals oriented to Sport Sciences such as the International Journal of Sports Medicine and the Journal of Sports Medicine and Physical Fitness predominated.

On the other hand, Archives of Budo, the only martial arts and combat sports oriented journal, published the highest number of articles (36) and achieved moderate citations from other taekwondo articles (TLCS) and one of the highest impact within the WoS (TGCS). In the case of judo, Archives of Budo presented a main role in the dissemination of articles, publishing 42 papers in total, but citation indexes were lower than those presented in taekwondo research (PESET et al., 2013). Despite the present study included a longer time span analyzed, until 2016, judo research presented a higher number of articles but citation scores were lower. As it was mentioned before, the important rise in the number of articles from 2010 to 2016 depicted in taekwondo should be also expected for judo research and probably, to a greater extent, citation scores would be higher for all journals. Therefore, there is no relationship between 
the amount of articles published in each journal and the number of cites received by the own articles and journals. A predominance of sport sciences-oriented journals was clearly observed for the spreading of taekwondo publications, suggesting MA\&CS research field is in a first phase of development with a limited number - just one - of MA\&CS journals being included in the selected databases. Moreover, the present results have confirmed the sporting approach guiding taekwondo research (PÉREZ-GUTIÉRREZ et al., 2015), depicted on the research areas and subjects supporting these studies, the topics presented and the orientation of journals publishing these articles.

Finally, the main limitation of the present study was the use of one database (WoS) for data mining, which probably underestimated the amount of articles, authors, institutions and countries developing and collaborating on taekwondo research. The inclusion of other databases could provide a more accurate approach to the analysis of taekwondo scientific community's structure and interests, but WoS was selected as one of the most important databases, providing bibliographic data from 1900 onwards (GASPARYAN, 2013).

\section{CONCLUSION}

The scientific production about taekwondo published in the WoS has shown predominance of Life Sciences research area; with Biomechanics, Sports Medicine and Physiology guiding research in this field of knowledge. Academics have been focused on the analysis of the biomechanical, physiological and nutritional aspects of taekwondo, using sport sciences-oriented journals for the dissemination of their publications. In this way, the relevance of taekwondo sporting approach has been corroborated through the analysis of research areas, subjects, topics and the orientation and citation scores of journals.

Taekwondo research indexed in the WoS has been mainly developed collaboratively among authors, institutions and countries. In general, collaboration networks are characterized by all academics working together and pertaining to a maximum of five different institutions and countries. However, the most productive author showed a different pattern of collaboration, centralizing the relationships of his network, depicting the largest amount of collaborators but one of the lowest collaboration indexes.

Finally, the methodological approach developed in the present study for article classification has presented clear differences in relation to WoS classification criteria, offering a more realistic approach to research areas, subjects and topics related to taekwondo research.

\section{REFERENCES}

AENOR, Agencia Española de Normalización. UNE-ISO 690-2013. Información y documentación. Directrices para la redacción de referencias bibliográficas y de citas de recursos de información. Madrid: Agencia Española de Normalización, 2013.

ANDRÉS, Ana. Measuring Academic Research: How to Undertake a Bibliometric Study. Oxford: Chandos, 2009. 
ČIHOUNKOVÁ, Jitka; REGULI, Zdenko. A Search of Literature on Karate Published in the Czech Republic. In: CYNARSKI, Wojciech Jan. Selected Areas of Intercultural Dialogue in Martial Arts. Rzeszow: Wydawnictwo universytetu Rzeszowskiego, 2011. p. 101-109.

COTA-GUAJARDO, Susana. Evaluation of Taekwondo's Scientific Activity through a Bibliometric Analysis. In: The 4th International Symposium for Taekwondo Studies, 4, 2013. Strengthening Youth Education through Taekwondo. Puebla, México: World Taekwondo Federation, 2013. p. 37-39. Available at: <http://www.jiatr.org/data/2013 mexico.pdf>. Accessed on: 19 jul. 2017.

DEVÍS-DEVÍS, José et al. Disciplinas y temas de estudio en las ciencias de la actividad física y el deporte. Revista Internacional de Medicina y Ciencias de la Actividad Física y del Deporte, v. 10, n. 37, p. 150-166, 2010.

GASPARYAN, Armen Y. Bibliographic Databases: Some Critical Points. Journal of Korean Medical Science, v. 28, n. 6, p. 799-800, 2013.

GUTIÉRREZ-GARCÍA, Carlos; BRIEVA-ORTEGA, Javier; PÉREZ-GUTIÉRREZ, Mikel. Repertorio provisional de revistas de artes marciales asiáticas publicadas en España (19612009). Revista de Artes Marciales Asiáticas, v. 6, n. 1, p. 83-116, 2011.

GUTIÉRREZ-GARCÍA, Carlos; PÉREZ-GUTIÉRREZ, Mikel. Study on scientific production in martial arts in Spain from 1990 to present. In: CYNARSKI, Wojciech Jan. Martial Arts and Combat Sports - Humanistic Outlook. Rzeszow: Wydawnictwo Uniwersytetu Rzeszowskiego, 2009. p. 90-115.

IATR. International Association for Taekwondo Research. Introduction of JIATR. Available at: <http://www.jiatr.org/jiatr/index.html?gubun=1>. Accessed on: 19 jul. 2017.

ITA. International Taekwon-Do Association. Tae Kwon Do Journal. Publication for the Traditional and Combat Martial Artist. Available at: <https://www.itatkd.com/tkdjournal.html>. Accessed on: 19 jul. 2017

ITF. International Taekwon-Do Federation. Taekwon-Do Research Journal. Available at: <http:// itfofficial.nu/research-journal/>. Accessed on: 19 jul. 2017.

ITRC. International Taekwondo Research Consortium. International Taekwondo Research Consortium. Available at: <http://itkdrc.blogspot.cl/>. Accessed on: 19 jul. 2017.

KUKKIWON. Taekwondo Journal of Kukkiwon. Available at: <https://research.kukkiwon.or.kr/ modules/doc/index.php?doc=non12\& M ID=189>. Accessed on: 19 jul. 2017.

LEE, Jae Don. Journal Status Analysis of Entitled Taekwondo in SCI (SCI, SCIE, SSCI, A\&HCl) and SCOPUS Journals. Taekwondo Journal of Kukkiwon, v. 6, n. 3, p. 81-105, 2015.

LÓPEZ LÓPEZ, Pedro. Introducción a la bibliometría. Valencia: Promolibro, 1996.

MASTAEKWONDO. Inicio. Santa Marta, 2017. Available at: <http://mastkd.com/>. Acessed on: 19 jul. 2017.

PÉREZ-GUTIÉRREZ, Mikel. Repertorio bibliográfico, análisis bibliométrico y sociocultural de las monografías de artes marciales asiáticas publicadas en España. León: Secretariado de Publicaciones, Universidad de León, 2012.

PÉREZ-GUTIÉRREZ, Mikel; GUTIÉRREZ-GARCÍA, Carlos. Estudio bibliométrico sobre las monografías de artes marciales publicadas en España (1906-2006). Revista de Artes Marciales Asiáticas, v. 3, n. 4, p. 22-33, 2008. 
PÉREZ-GUTIÉRREZ, Mikel; GUTIÉRREZ-GARCÍA, Carlos. Bibliometric analysis of karate monographs in Spain (1963-2006). In: CYNARSKI, Wojciech Jan. Martial Arts and Combat Sports - Humanistic Outlook. Rzeszow: Wydawnictwo universytetu Rzeszowskiego, 2009. p. 116-126.

PÉREZ-GUTIÉRREZ, Mikel; GUTIÉRREZ-GARCÍA, Carlos; ESCOBAR-MOLINA, Raquel. Terminological recommendations for improving the visibility of scientific literature on martial arts and combat sports. Archives of Budo, v. 7, n. 3, p. 159-166, 2011.

PÉREZ-GUTIÉRREZ, Mikel et al. Bibliometric analysis of taekwondo articles published in the Web of Science (1989-2013). IDO Movement for Culture. Journal of Martial Arts Anthropology, v. 15, n. 3, p. 8-21, 2015.

PÉREZ-GUTIÉRREZ, Mikel; VALDÉS-BADILLA, Pablo Antonio. Evolución de la investigación iberoamericana relativa al taekwondo y su impacto en el ámbito deportivo: aproximación bibliométrica. Lúdica Pedagógica, v. 20, n. 2, p. 103-112, 2014.

PESET, Fernanda et al. Scientific literature analysis of Judo in Web of Science. Archives of Budo, v. 9, n. 2, p. 81-91, 2013.

SVINTH, Joseph R. Korea: Taekwondo. In: GREEN, Thomas A.; SVINTH, Joseph R. Martial Arts of the World. An Encyclopedia of History and Innovation. Santa Barbara (CA): ABC-CLIO, 2010. p. 199-205.

TAEKWONDO RADIO. Noticias. Available at: < https://www.taekwondoradio.com/>. Accessed on: 19 jul. 2017.

TAEKWONDODATA. Home. Available at: <http://www.taekwondodata.com/>. Accessed on: 19 jul. 2017.

TAEKWONDOSCIENCE. Home. Available at: <http://www.taekwondoscience.com/>. Accessed on: 19 jul. 2017.

THOMSON REUTERS. Using bibliometrics: A guide to evaluating research performance with citation data. 2008. Available at: <http://ip-science.thomsonreuters.com/m/pdfs $/ 325133$ thomson. pdf>. Accessed on: 19 jul. 2017.

THOMSON REUTERS. Web of Science $\mathbf{8 . 0}$ Workshop: Science Citation Index Expanded, Social Sciences Citation Index, Arts \& Humanities Citation Index. 2009.

THOMSON REUTERS. Web of Science Core Collection Help. Research Areas (Categories/ Classification). Available at: < https://images.webofknowledge.com/images/help/WOS/hp research areas easca.html>. Accessed on: 19 jul. 2017.

TKD TIMES. Home. Available at: <http://www.taekwondotimes.com/index.php>. Accessed on: 19 jul. 2017.

VALENCIANO VALCÁRCEL, Javier et al. La colaboración científica en el campo de las Ciencias de la Actividad Física y el Deporte en España. Revista Española de Documentación Científica, v. 33, n. 1, p. 90-105, 2010.

VIT, Michel; REGULI, Zdenko . Systematized Review of Czech Literature on Combatives and Self-defence. In: CYNARSKI, Wojciech Jan. Selected Areas of Intercultural Dialogue in Martial Arts. Rzeszow: Wydawnictwo Universytetu Rzeszowskiego, 2011. p. 83-100. 
WIZDOM .Al. Taekwondo. Available at: <https://wizdom.ai/dashboards/olympics-research/ taekwondo>. Accessed on: 19 jul. 2017.

WTF. World Taekwondo Federation. Magazine Taekwondo. Available at: <http://www. worldtaekwondo.org/magazine/>. Accessed on: 19 jul.2017. 
